\title{
Corrosion Behavior of Laser Remelted CoNiCrAIY Based Composite Coatings
}

\author{
Dragos Utu ${ }^{1}$, Gabriela Marginean ${ }^{2}$, Viorel-Aurel Serban ${ }^{1}$, Cosmin Codrean ${ }^{1}$ \\ ${ }^{1}$ University "Politehnica” Timisoara, Faculty of Mechanical Engineering, Timisoara, Romania \\ ${ }^{2}$ University of Applied Sciences Gelsenkirchen, Gelsenkirchen, Germany \\ E-mail: utu.dragos@mec.upt.ro \\ Received November 27, 2009; revised February 5, 2010; accepted February 12, 2010
}

\begin{abstract}
The corrosion behavior of High-Velocity Oxygen Fuel (HVOF) sprayed MCrAlY coatings obtained from CoNiCrAlY particles (wt. 8\% Al) mechanically doped with $\mathrm{Al}_{2} \mathrm{O}_{3}$ nanopowder was investigated before and after laser remelting. The latter process was applied in order to achieve a homogeneous structure as well as better mechanical properties for the coating (reduced brittleness offered by the presence of the $\mathrm{Al}_{2} \mathrm{O}_{3}$ nanoparticles). Another important task of the laboratory investigations was the investigation of the corrosion behavior of the modified coatings. The results obtained from the potentiodynamic polarization measurements carried out in a chloride environment revealed an enhanced corrosion resistance of the laser remelted coatings comprising a refined microstructure. Microhardness measurements of the modified coatings revealed lower values in comparison with that of the samples in as-sprayed status. This observation leads to the assumption that a concomitant improvement of coatings ductility occurred as well.
\end{abstract}

Keywords: Laser Remelting, Conicraly Coatings, Corrosion Behaviour

\section{Introduction}

In the turbine blades section of the engines, the overall operating conditions became progressively more hostile in terms of temperature and mechanical environment. A solution in order to solve this problem is applying of protective thermal barriers consisting of a ceramic insulating layer bonded to an oxidation resistant MCrAlY coating. The latter one belongs to the family of high temperature coatings (around $850-1200^{\circ} \mathrm{C}$ ), where $\mathrm{M}$ is selected from one or a combination of iron, nickel and cobalt $[1,2]$. $\mathrm{Cr}$ and $\mathrm{Al}$ are present in the MCrAlY chemical composition because they are able to form highly tenacious protective oxide scales [3], whilst Y promotes formation of these stable oxides [4]. Their protection role is given by the formation of a compact, stable, and adherent oxide layer (usually $\alpha-\mathrm{A}_{2} \mathrm{O}_{3}$ ) on the surface, which exhibits any interaction between the base material and the corrosive medium. Without this protective scale, the coating and ultimately the substrate, would come under rapid oxidation and/or corrosion attack [5]. The durability or service life of the MCrAlY coating depends mainly on the stability of the formed alumina scale [6].

The microstructure of the grown oxide scales depends strongly on the coating properties, the manufacturing process and the operating conditions.

In a previous research work it has been demonstrated that the mechanical alloying of MCrAlY powders with nano- $\mathrm{Al}_{2} \mathrm{O}_{3}$ leads $\mathrm{o}$ a better high temperature oxidation behavior of the HVOF-sprayed coating in comparison with the conventional MCrAlY coating. This conclusion is based mainly on the reduced oxidation rate of the $\mathrm{Al}_{2} \mathrm{O}_{3}$ doped MCrAlY coating, which is a very important parameter concerning the kinetics of the oxide scale growth $[7,8]$. Therefore, another supplementary task should be settled in the coatings investigation, namely their behavior under mechanical loadings. Doping of the MCrAlY coatings with ceramic particles which are uniformly distributed along the grain boundaries between the MCrAlY particles, showed the main disadvantage concerning its negative influence on the coating ductility (due to the presence of brittle compounds).

Rapid melting and solidifying of the MCrAlY coatings achieved using a laser beam can offer good mechanical behavior of the whole system (coating-substrate). 


\section{Experimental Procedures}

CoNiCrAlY coatings $(280-350 \mu \mathrm{m})$ with wt. $8 \%$ Al content (Co-32Ni-22Cr-8Al-0.5Y) and mechanically mixed with wt. $2 \% \mathrm{Al}_{2} \mathrm{O}_{3}$-nanopowder were sprayed onto an alloy 617 substrate $(5 \mathrm{~mm}$ thick) using the HVOF (High Velocity Oxygen-Fuel)-spraying technique.

The equipment used was a CJS Gun of the company Thermico, Germany, which is operated with a hydrogenstabilized liquid fuel oxygen combustion.

The coatings were remelted using a $\mathrm{CO}_{2}$ laser from TRUMPF company, by applying an unfocussed beam for a witdth about $100 \mathrm{~mm}$. The remelting treatment was performed using argon as shielding gas. The optimized parameters used during the laser treatment process are presented in Table 1. The beam power, $\mathrm{P}$ and the working distance, $\mathrm{d}$ were kept constant during the treatment, while advancing velocities, $\mathrm{v}$ were varied.

In order to determine the corrosion resistance of the coatings before and after laser remelting electrochemical measurements were also carried out. The tests were performed in a $5 \% \mathrm{H}_{2} \mathrm{SO}_{4}$ solution containing $58 \mathrm{~g} / \mathrm{L} \mathrm{NaCl}$, using an electrochemical corrosion cell and a potentiostat/galvanostat PGP201 from Radiometer.

Polarization curves were recorded in the positive direction starting from free potential at room temperature in a three electrode cell using calomel electrode (SCE) as reference. The applied potential was varied between -1000 and $1000 \mathrm{mV}$ using a rate of $50 \mathrm{mV} / \mathrm{min}$.
Table 1. Experimental conditions for laser remelting.

\begin{tabular}{cc|cccc}
\hline Material & $\begin{array}{c}\text { Coating } \\
\text { thickness } \\
{[\mu \mathrm{m}]}\end{array}$ & \multicolumn{3}{|c}{$\begin{array}{l}\text { Remelting } \\
\text { parameters }\end{array}$} & $\begin{array}{l}\text { Penetration } \\
\text { depth }[\mu \mathrm{m}]\end{array}$ \\
\hline & & $\mathrm{P}$ & $\mathrm{d}$ & $\mathrm{v}$ & \\
CoNiCrAlY & $280-350$ & {$[\mathrm{~kW}]$} & {$[\mathrm{mm}]$} & {$[\mathrm{mm} / \mathrm{s}]$} & \\
\cline { 3 - 6 } & & 3 & 310 & 5 & 239 \\
& & & & 10 & 110 \\
\hline
\end{tabular}

\section{Results and Discussions}

\subsection{Coatings Morphology}

SEM-investigation of the as-sprayed coating (Figure 1) shows the presence of oxides in the structure of the material. It can be seen that the deformation degree of the CoNiCrAlY particles during spraying was not very pronounced. The insulating $\mathrm{Al}_{2} \mathrm{O}_{3}$ ceramic nanoparticles form a thermal barrier for the MCrAlY powders which are exposed to a reduced thermal energy during the HVOF spraying process. This phenomenon is demonstrated by the presence of partially molten particles.

Depending on the parameters of the laser remelting treatment (see Table 1), different penetration depths were obtained (compare Figure 2(a) with 3(a)). Increasing the advancing velocity of the remelting process led to a reduced penetration depth as well as to a finer coating microstructure (Figure 2(b) respectively 3(b)). In both

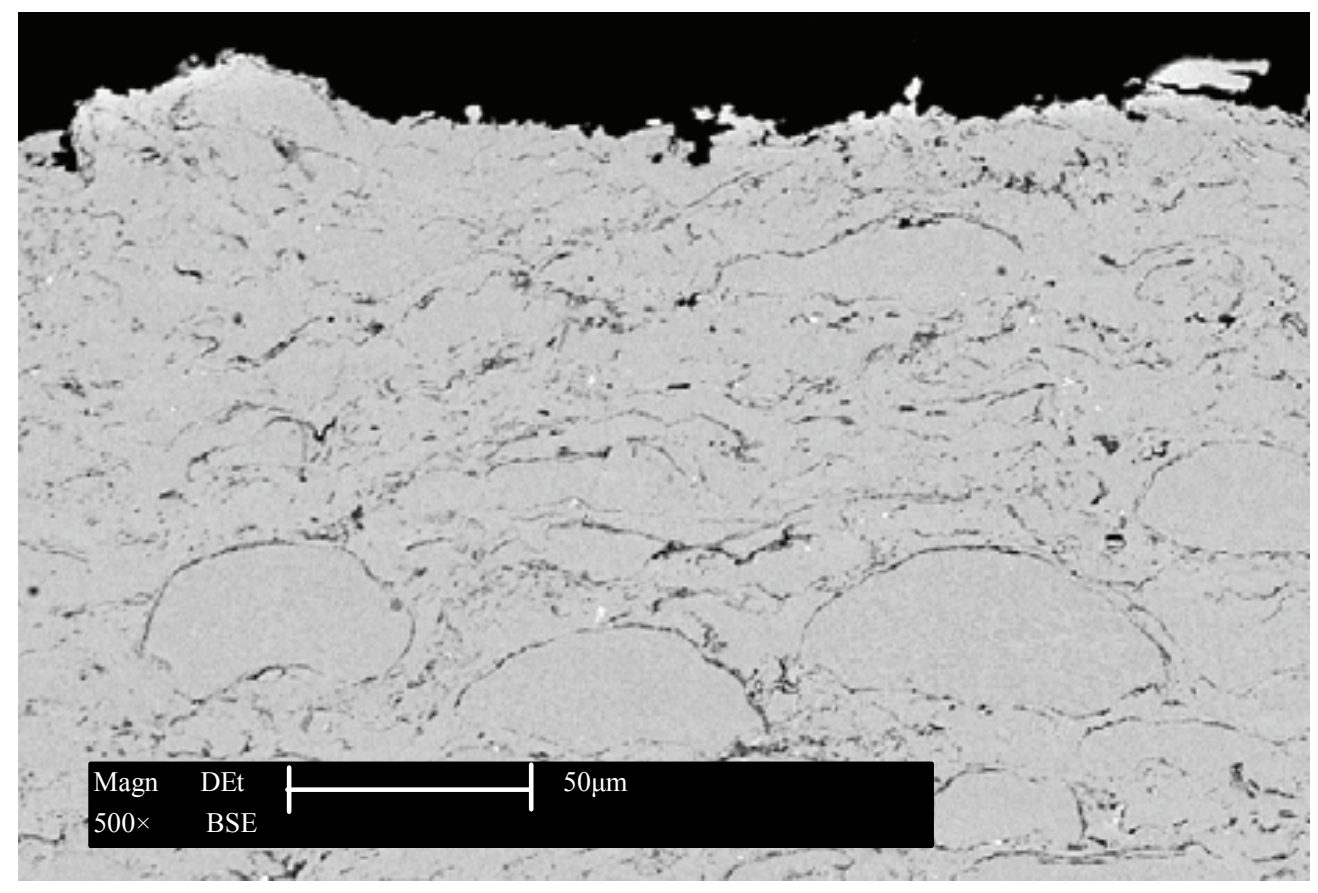

Figure 1. SEM micrograph (cross-section) of the as-sprayed $\mathrm{MCrAIY}+2 \% \mathrm{Al}_{2} \mathrm{O}_{3}$ coating [8].

Identify applicable sponsor/s here. (sponsors) 


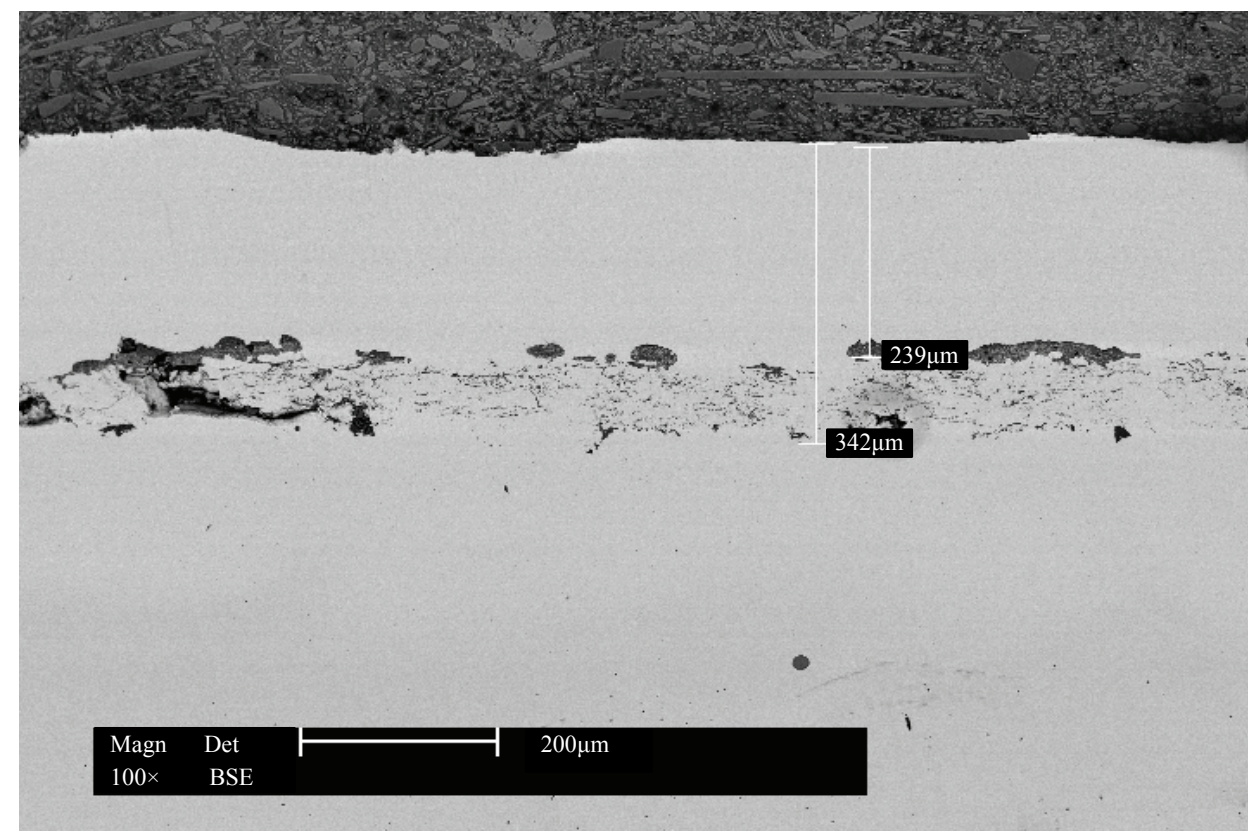

(a)

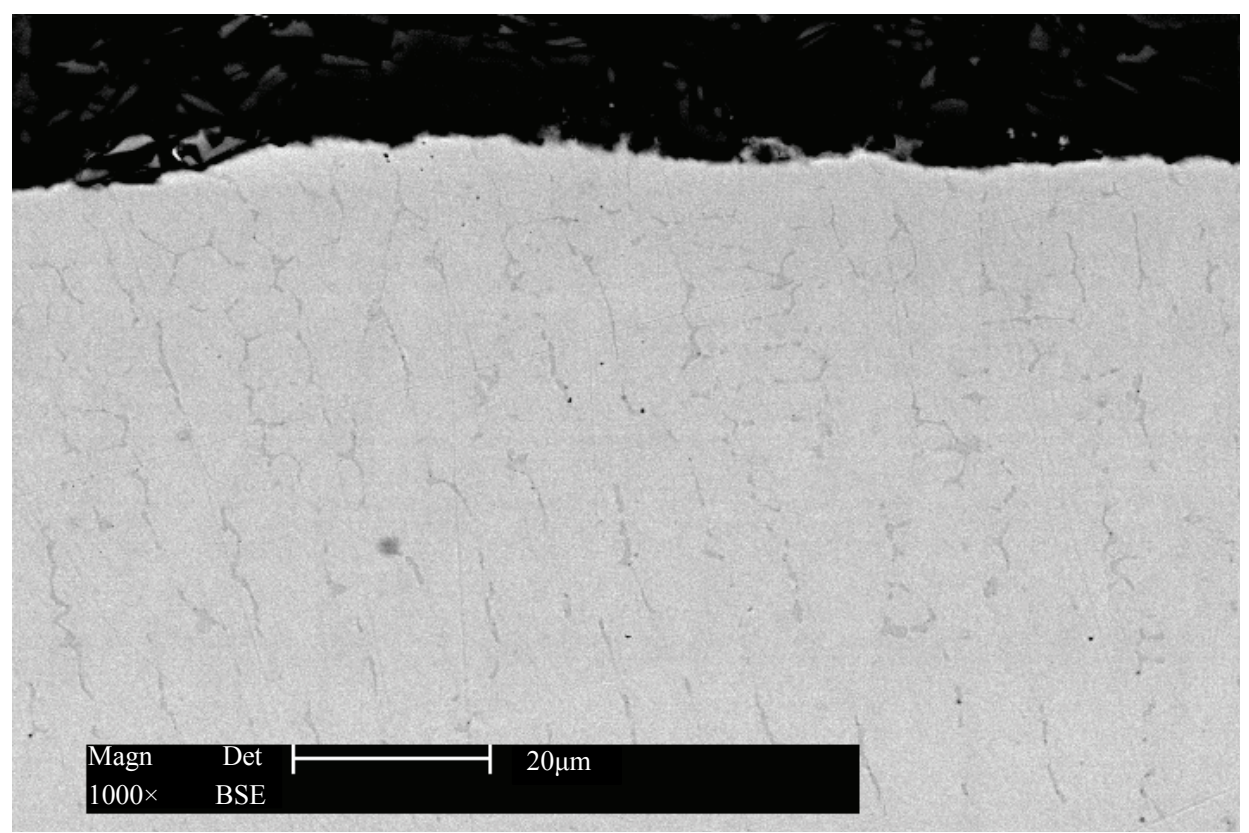

(b)

Figure 2. SEM micrographs of the laser remelted coatings $(\mathrm{v}=5 \mathrm{~mm} / \mathrm{s})$.

cases the remelted zone was free from pores and oxides.

\subsection{X-ray Diffraction Measurements}

The X-ray diffraction tests were performed on a Philips $\mathrm{X}$ 'Pert $\mathrm{X}$-ray diffractometer using a $\mathrm{Cu}-\mathrm{K}_{\alpha}$ radiation, in order to determine the phase composition of the coatings before and after laser remelting.
X-ray diffraction patterns (Figure 4) show for all the investigated samples the presence of a phase-mixture consisting of $\gamma-\mathrm{Ni} / \gamma^{\prime}-\mathrm{Ni}_{3} \mathrm{Al}, \beta-\mathrm{NiAl}, \alpha-\mathrm{Al}_{2} \mathrm{O}_{3}$ and $\mathrm{Cr}_{2} \mathrm{O}_{3}$.

The XRD patterns from Figure 4 indicate that in the case of the laser remelted samples the $\mathrm{Al}_{2} \mathrm{O}_{3}$ oxide phase was partially dissolved in solution increasing the matrix content $\gamma-\mathrm{Ni} / \gamma-\mathrm{Ni}_{3} \mathrm{Al}$. The appearance of the $\beta$-NiAl phase can be also noticed (phase precipitation during the 
laser remelting process - see the dark-grey cellular structures on the SEM-micrographs Figure 2(b) respectively 3(b)).

\subsection{Microhardness Tests}

The microhardness of the coatings was measured with a
Vickers tester from Wolpert applying a $0.1 \mathrm{kgf}$ load. The reported values (Figure 5) represent the indentations made along the coating cross-section, where P0 is the as-sprayed coating and $\mathrm{P} 1$ and $\mathrm{P} 2$ are the laser remelted coatings using $\mathrm{v}=5 \mathrm{~mm} / \mathrm{s}$ respectively $\mathrm{v}=10 \mathrm{~mm} / \mathrm{s}$.

The hardness curves evidence that the laser remelting

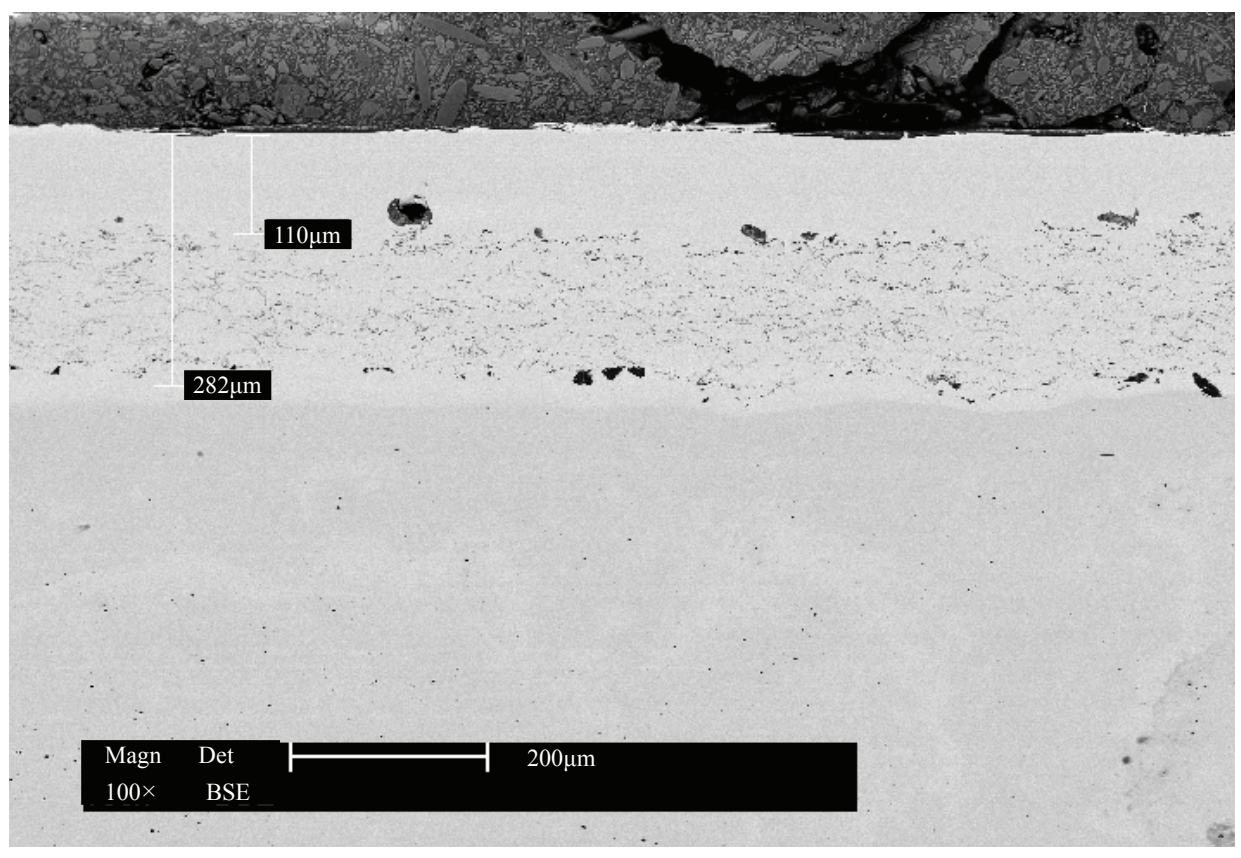

(a)

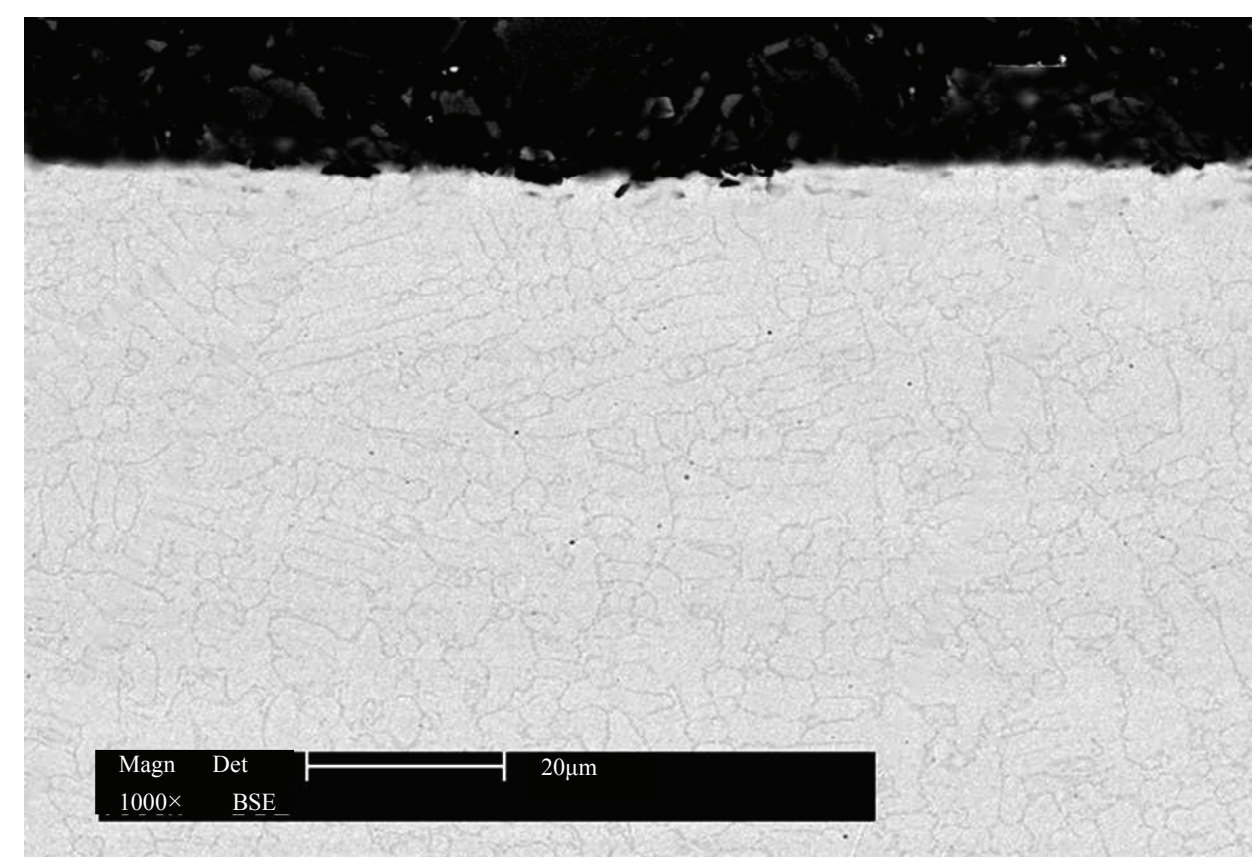

(b)

Figure 3. SEM micrographs of the laser remelted coatings $(\mathrm{v}=10 \mathrm{~mm} / \mathrm{s})$. 


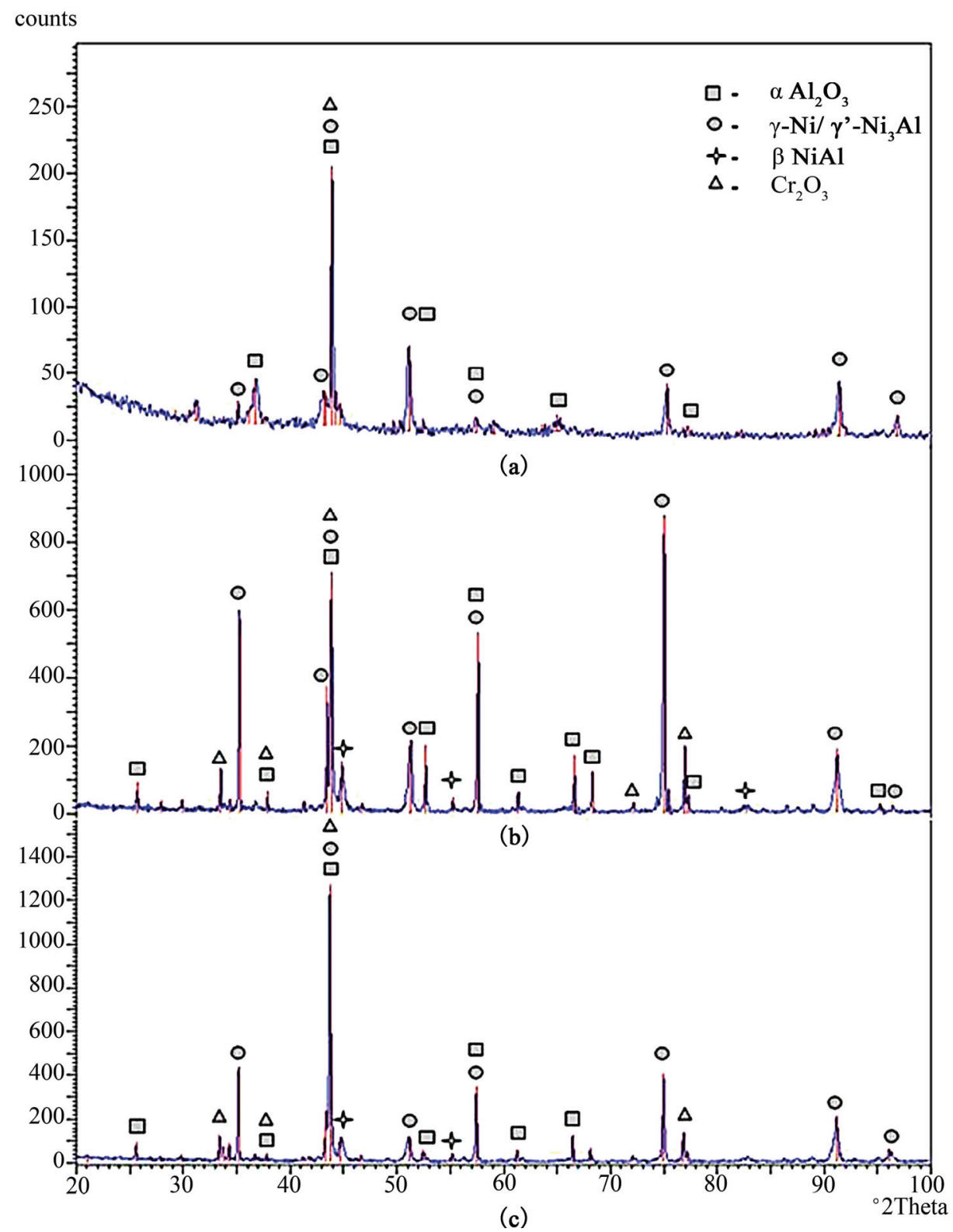

Figure 4. XRD diffraction patterns: a-as sprayed sample, b-laser remelted v $=5 \mathrm{~mm}$, c-laser remelted $\mathrm{v}=10 \mathrm{~mm}$.

process led to decreasing of the values from $450 \mathrm{HV}$ to almost $200 \mathrm{HV}$. This result has a positive effect on the ductility of the material. The values of the measured hardness along the coating thickness correlate very well with the structures shown in the Figures 2(a) and 3(a). In the domain where the $\mathrm{Al}_{2} \mathrm{O}_{3}$ particles were dissociated by the laser energy, the coating has a lower hardness in comparison with the zones where the oxide particles are steel present.

\subsection{Corrosion Tests}

The polarization curves obtained for the tested materials (P0, P1 and P2) are presented in Figure 6.

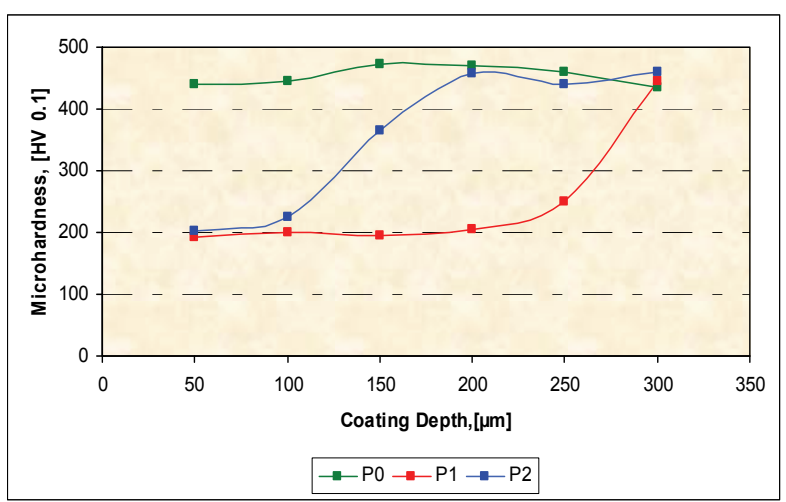

Figure 5. Microhardness curves of the tested materials. 


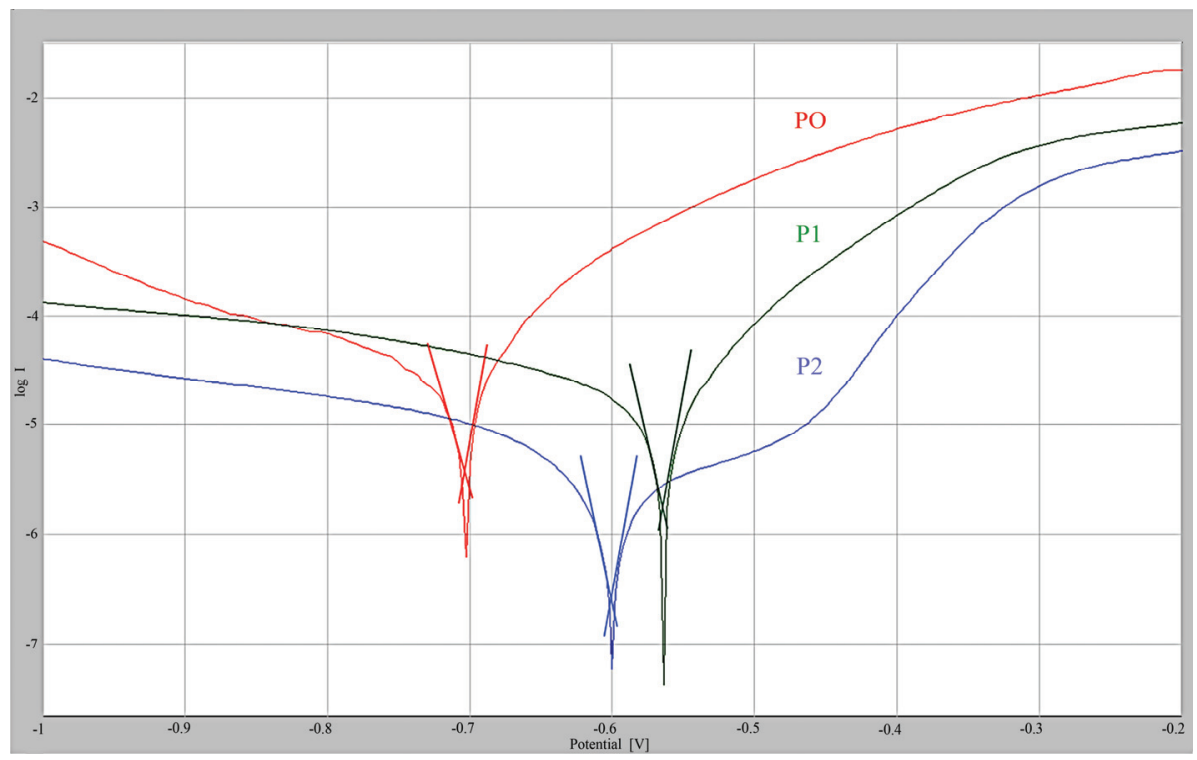

Figure 6. Polarization curves of the samples exposed in $5 \% \mathrm{H}_{2} \mathrm{SO}_{4}$ with $58 \mathrm{~g} / \mathrm{L} \mathrm{NaCl}$.

Table 2. Values of the measured corrosion potential and current density.

\begin{tabular}{ccc}
\hline \multirow{2}{*}{ Sample } & \multicolumn{2}{c}{ Electrochemical data } \\
\cline { 2 - 3 } & $\mathrm{i}_{\text {corr }}\left(\mu \mathrm{A} / \mathrm{cm}^{2}\right)$ & $\mathrm{E}_{\text {corr }}(\mathrm{mV})$ \\
\hline P0 & 95.4 & -685.9 \\
P1 & 17.5 & -550.4 \\
P2 & 1.71 & -592.2 \\
\hline
\end{tabular}

Comparing the determined results for the corrosion current density $\left(i_{\text {corr }}\right)$ it can be seen that the values of the laser remelted coatings (Table 2) were shifted to lower values in comparison with $\mathrm{P} 0$ (from $95.4 \mu \mathrm{A} / \mathrm{cm}^{2}$ to 17.5 respectively $1.71 \mu \mathrm{A} / \mathrm{cm}^{2}$ ) which means an improving of the corrosion behavior in chloride environment compared with the as-sprayed sample.

\section{Conclusions}

The investigations performed show a general improveement of the coating properties due to the advantageous microstructure of the remelted composite powder obtained by applying a $\mathrm{CO}_{2}$ laser beam.

The corrosion behavior in a $5 \% \quad \mathrm{H}_{2} \mathrm{SO}_{4}$ solution containing $58 \mathrm{~g} / \mathrm{L} \mathrm{NaCl}$ of the HVOF sprayed CoNiCrAlY coatings (wt. $8 \% \mathrm{Al}$ ) doped with $\mathrm{Al}_{2} \mathrm{O}_{3}$ nanopowder was investigated before and after laser remelting. The experimental results demonstrated that the laser treatment had a positive effect on the corrosion resistance of the coatings because of the structure refining (free from pores and oxides).

Moreover, the ductility of the tested CoNiCrAlY coatings mechanically doped with $\mathrm{Al}_{2} \mathrm{O}_{3}$ nanopowder was improved by laser irradiation. It has been found a hardness decreasing of the refined structure.

\section{References}

[1] T. A. Taylor and D. F. Bettridge, "Development of Alloyed and Dispersion-Strengthened Mcraly Coatings," Surface and Coatings Technology, Vol. 86-87, No. 1, 1996, pp. 9-14.

[2] A. Weisenburger, G. Rizzi, A. Scrivani, G. Mueller and J. R. Nicholls, "Pulsed Electron Beam Treatment of Mcraly Bondcoats for EB-PVD TBC Systems Part 1 of 2: Coating Production," Surface and Coatings Technology, Vol. 202, 2007, pp. 704-708.

[3] L. Lelait, S. Alpérine and R. Mévrel, "Alumina Scale Growth at Zirconia-Mcraly Interface: A Microstructural Study," Journal of Materials Science, Vol. 27, 1992, pp. 5-12.

[4] L. Russo, M. Dorfman and K. Lapierre, "Superalloy HVOF Powders with Improved High Temperature Oxidation, Corrosion and Creep Resistance," European Patent EP1272301, Sulzer Metco Us Inc., Westbury, 2003.

[5] "NMAB: Coatings for High-Temperature Structural Materials: Trends and Opportunities," National Academy Press, Washington, D.C., 1996.

[6] H. Al-Badairy, G. Tatlock, S. Fawcett, P. Beahan and J. Hunt, "FEG-SEM Investigation of Alumina Scales Formed on Fecraly Alloys Oxidised at $1200^{\circ} \mathrm{C}$," Journal de Physique IV France, Vol. 124, 2005, pp. 17-24.

[7] D. Maghet, G. Marginean, I. Mitelea, A. Davidescu and W. Brandl, "Comparison of Oxidation Behaviour of Various Thermally Sprayed MCrAlY Coatings", The European Corrosion Congress, Breisgau, 2007.

[8] D. Maghet "Morphology and Properties of HVOF-MCrAlY Sprayed Coatings," Ph.D. Thesis, Politehnica University of Timisoara, Timisoara, 2007. 